\title{
Productivity and water demand of maize estimated by the modified satellite Priestley-Taylor algorithm
}

\section{Produtividade e demanda hídrica do milho estimado pelo algoritmo de Priestley-Taylor modificado para satélite}

\author{
Roberto Filgueiras $^{1 *}$; Everardo Chartuni Mantovani²; Daniel Althoff ${ }^{1}$; Santos \\ Henrique Brant Dias ${ }^{3}$; Fernando França da Cunha ${ }^{2}$; Luan Peroni Venancio ${ }^{1}$
}

\begin{abstract}
The water demand of crops, as well as the relation of this variable to productivity and other important factors related to the sustainable management of agriculture, makes it relevant to estimate parameters that help in the most assertive and efficient decision-making in the agricultural environment. In this context, the work aims to estimate the actual evapotranspiration (ETa), biomass (Bio), water productivity (WP) and crop productivity (P), using the Landsat-8 satellite, through the Modified Satellite Priestley-Taylor Algorithm (MS-PT). For this, ETa was estimated for maize culture irrigated by central pivots, using the MS-PT with six images of Landsat-8, which were free of clouds. The ETa estimate was accurate in the first 60 days after emergence (DAE) of the crop. Subsequently, the variables Bio, P, and WP were estimated using the ETa and the assumptions of the Monteith (1972) model. Therefore, we sequentially calculated the dry biomass, crop productivity and water productivity. ETa presented a high correlation with Bio from the second image (06/10/2015), due to the canopy closure of the crop and, consequently, the predominance of transpiration in the evapotranspiration phenomenon. The water productivity was constant throughout the maximum vegetative stage until the reproductive phase R4 of the crop, verifying in this interval the best efficiency in the conversion of water in biomass. From the obtained results, it is verified that the set of algorithms used in the estimation of the parameters demonstrated the potential to increase the capacity to handle agriculture in a more efficient, assertive and sustainable way.
\end{abstract}

Key words: Landsat-8. Evapotranspiration. Biomass. Sustainable agriculture. Crop management.

\section{Resumo}

A demanda hídrica das culturas, assim como a relação dessa com variáveis de produtividade e outros importantes fatores relacionados ao manejo da agricultura sustentável, faz com seja relevante a estimação de parâmetros que auxiliam de modo assertivo e eficiente a tomada de decisão no ambiente agrícola. Nesse contexto, o objetivo desse trabalho foi estimar a evapotranspiração real (ETa), biomassa (Bio), produtividade da água (WP) e a produtividade da cultura (P), utilizando imagens do satélite Landsat-8, por meio do algoritmo Priestley-Taylor modificado para satélite (MS-PT). Para isso, estimou-se a ETa para a cultura do milho irrigado por pivôs central, utilizando o MS-PT com seis imagens do Landsat- 8 , as quais encontravam-se livre de nuvens. A estimativa da ETa foi acurada nos

1 Discentes de Doutorado, Universidade Federal de Viçosa, Departamento de Engenharia Agrícola, DEA/UFV, Viçosa, MG, Brasil. E-mail: roberto.f.filgueiras@ufv.br; daniel.althoff@ufv.br; lpagronomo1990@gmail.com

2 Profs., Drs., Departamento de Engenharia Agrícola, DEA/UFV, Viçosa, MG, Brasil. E-mail: everardo@ufv.br; fernando.cunha@ ufv.br

3 Discente de Doutorado, Universidade Estadual de Ponta Grossa, Departamento de Ciência do Solo e Engenharia Agrícola, DCSEA/UEPG, Ponta Grossa, PR, Brasil. E-mail: santosdiasagro@gmail.com

Author for correspondence 
primeiros 60 dias após a emergência (DAE) da cultura. Posteriormente, as variáveis Bio, $\mathrm{P}$, e WP foram estimadas utilizando a ETa e os pressupostos do modelo de Monteith (1972). A ETa apresentou alta correlação com a Bio a partir da segunda imagem (10/06/2015), em função do fechamento dossel da cultura e consequentemente a predominância da transpiração no fenômeno de evapotranspiração. A WP foi constante durante o máximo crescimento vegetativo até a fase reprodutiva da cultura denominada $\mathrm{R} 4$, sendo verificado nessa amplitude de tempo a melhor eficiência da conversão de água em biomassa. A partir dos resultados obtidos, verifica-se que esse conjunto de algoritmos utilizados para estimativa dos parâmetros relacionados a produtividade do milho mostraram o potencial de crescimento que se tem para melhorar a capacidade de como lidar com uma agricultura mais eficiente, assertiva e sustentável.

Palavras-chave: Landsat-8. Evapotranspiração. Biomassa. Agricultura sustentável. Manejo das culturas.

\section{Introduction}

Knowledge of the water demand of crops, as well as their relationship with productivity, is an important indicator for the sustainable management of agriculture, making it possible to maximize efficiency in the use of available resources (FENG et al., 2017b; TOUREIRO et al., 2017). Knowing precisely these parameters makes the management of agricultural properties more assertive and efficient, both in terms of irrigation management (ADNAN et al., 2017; FENG et al., 2017a) and in the selection of the most appropriate cultivars for each situation. Besides that, anticipated information is valuable for production planning, management, and post-harvest procedures (BERTOLIN et al., 2017).

Actual evapotranspiration (ETa) has been satisfactorily estimated with the use of satellite images along with meteorological data (CARRILLO-ROJAS et al., 2016). There are numerous algorithms based on satellite images to estimate this parameter, both physical and empirical (ZHANG et al., 2016). Some of the well-known algorithms are: SEBAL - Surface Energy Balance Algorithm for Land (BASTIAANSSEN et al., 1998); METRIC - Mapping EvapoTranspiration at high Resolution with Internalized Calibration (ALLEN et al., 2007); R-SSEB - Regional Simplified Surface Energy Balance (ARAÚJO et al., 2017); two-layer models (KUSTAS et al., 1996); SAFER - Simple Algorithm for Evapotranspiration Retrieving (TEIXEIRA, 2010); SSEBOP - Simplified Surface Energy Balance (SENAY et al., 2016); and MS-PT - Modified Satellite Priestley-Taylor (YAO et al.,

\section{3; ZHANG et al., 2017a).}

Among the existing algorithms widespread in the literature(SILVAetal., 2017), the MS-PT is presented as an attractive alternative for ETa estimation. In addition to simple execution, this algorithm has the ability to partition evapotranspiration, that is, compute separately transpiration and soil water evaporation, characteristics that are not found together in another model.

In the process of getting ETa, we obtain the evapotranspiration fraction from the ratio of the latent heat flux with the sum of the net radiation and the soil heat flux. The evapotranspiration fraction is also used in order to estimate the daily biomass (BASTIAANSSEN; ALI, 2003; COAGUILA et al., 2017), that is, the crop's dry mass increase on that day. The total dry biomass produced during the cycle is estimated by integration of the daily biomass obtained in the satellite overpass date, which can be converted to crop yield using a harvest index and the grain moisture at harvest time (BASTIAANSSEN; ALI, 2003).

It is possible to generate many benefits for irrigated agriculture with the implementation of the MS-PT model. The biomass/evapotranspiration ratio allows, for instance, the producers to list which cultivars are most responsive to water. This information can also be used as an important environmental indicator (water footprint), given the pressure to minimize the environmental impacts in agricultural activities (MORILLO et al., 2015) and to reduce water use conflicts. 
Besides that, if yield is accurately estimated in advance, it is possible to optimize the crop management activities, since it will be a fully programmed and adequate operation for the crop production (BERTOLIN et al., 2017; LOBELL et al., 2015).

With the ability to couple satellite images and algorithms, we show a potential alternative to estimate parameters that can be useful for crop irrigation management and productivity prediction. In this context, the objectives of this work are to estimate evapotranspiration, biomass, water productivity and crop yield, utilizing the Landsat- 8 images, along with the Modified Satellite PriestleyTaylor Algorithm (MS-PT).

\section{Material and Methods}

The study was conducted in an area located in the western part of the state of Bahia, Brazil, between the pairs of projected coordinates X1 - 416,840; Y1 - 8,627,100 and X2 - 43,940; Y2 - 8,616,420, datum WGS-84, UTM (Universal Transverse Mercator) projection, zone $23 \mathrm{~S}$ (Figure 1). The area of study refers to five central pivots, where the maize crop was cultivated at the time of the study.

Figure 1. Location of the five central pivots (study area), in relation to Brazil, state of Bahia and the mesoregion of western Bahia.

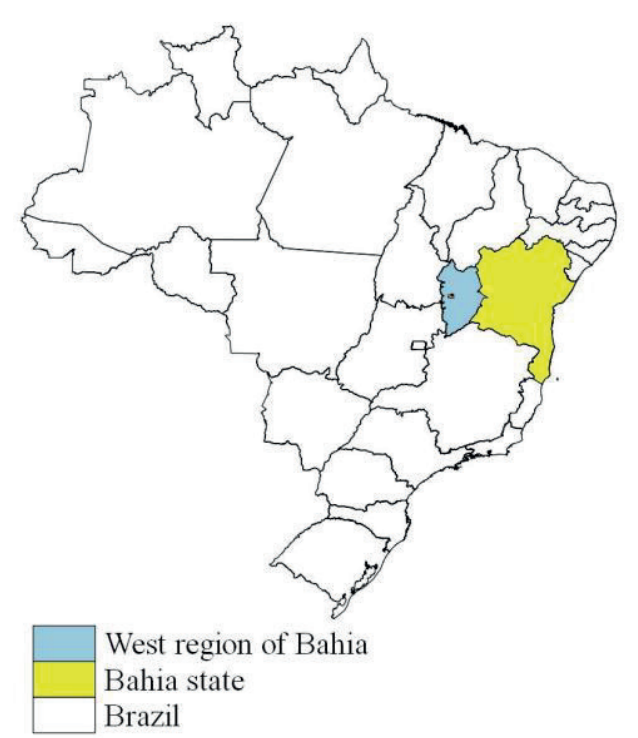

The satellite data used in the research are from Landsat-8, product C1 level 1, path/row 220/069, collected by OLI (Operational Land Imager) and TIRS (Thermal Infrared Sensor) sensors. Landsat- 8 has a spatial resolution of 30 meters for the OLI sensor bands, with the exception of the panchromatic band (15 meters), and 100 meters for two bands from the TIRS sensor, that have 100 meters of spatial resolution (ROY et al., 2014).
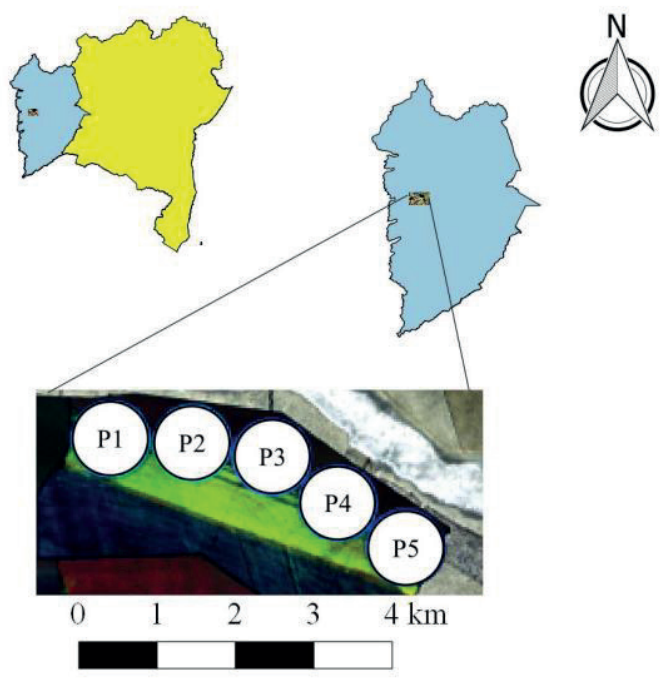

The actual evapotranspiration (ETa), biomass (Bio), water productivity (WP) and productivity (P) can be estimated with the bands 2, 3, 4, 5, 6, 7 and 10 of the Landsat- 8 . The wavelength amplitudes of the electromagnetic spectrum of the bands used are following: blue $(0.450-0.515 \mu \mathrm{m})$; green $(0.525$ $0.600 \mu \mathrm{m})$; red $(0.630-0.680 \mu \mathrm{m})$; near infraredNIR (0.845-0.885 $\mu \mathrm{m})$; Short Wavelength Infrared SWIR1 (1.560-1.660 $\mu \mathrm{m})$ and SWIR2 (2.100-2.300 $\mu \mathrm{m})$; and Long Wavelength Infrared B10 - Thermal B10 (10.30-11.30 $\mu \mathrm{m})$, respectively. 
During the maize crop cycle, which lasted from 09/05/2015 (beginning of the first planting - pivot 1) to $24 / 09 / 2015$ (end of the cycle), six cloud-free satellite images were obtained, which referred to the following dates: $25 / 05 / 2015 ; 10 / 06 / 2015$;
$28 / 07 / 2015 ; \quad 13 / 08 / 2015 ; \quad 29 / 08 / 2015 ; \quad$ and $14 / 09 / 2015$.

Table 1 shows the days after the emergence in each central pivot for the images dates.

Table 1. Vegetative period of maize crop in different dates and central pivots.

\begin{tabular}{|c|c|c|c|c|c|c|}
\hline \multirow{2}{*}{$\begin{array}{l}\text { Central Pivot/ } \\
\text { dates }\end{array}$} & $25 / 05$ & $10 / 06$ & $28 / 07$ & $13 / 08$ & $29 / 08$ & $14 / 09$ \\
\hline & \multicolumn{6}{|c|}{$\mathrm{DAE}^{*}$} \\
\hline 1 & 9 & 25 & 73 & 89 & 105 & 121 \\
\hline 2 & 6 & 22 & 70 & 86 & 102 & 118 \\
\hline 3 & 5 & 21 & 69 & 85 & 101 & 117 \\
\hline 4 & 3 & 19 & 67 & 83 & 99 & 115 \\
\hline 5 & 2 & 18 & 66 & 82 & 98 & 114 \\
\hline
\end{tabular}

* Days after emergence.

\section{Methodology}

The processing of the data was performed in a given sequence (Figure 2), since some parameters were necessary for the calculation of others. Thus, the first operation performed was the preprocessing of Landsat- 8 images, that is, the conversion of digital numbers to physical values (PONZONI et al., 2012) and atmospheric correction by means of dark-object subtraction methodology (CHAVEZ, 1988), with the exception of the thermal band. Subsequently, the daily ETa was calculated, following the assumptions of the MS-PT model (YAO et al., 2013; ZHANG et al., 2017a).

Figure 2. Methodological steps to estimate evapotranspiration, daily biomass, water productivity and crop production.

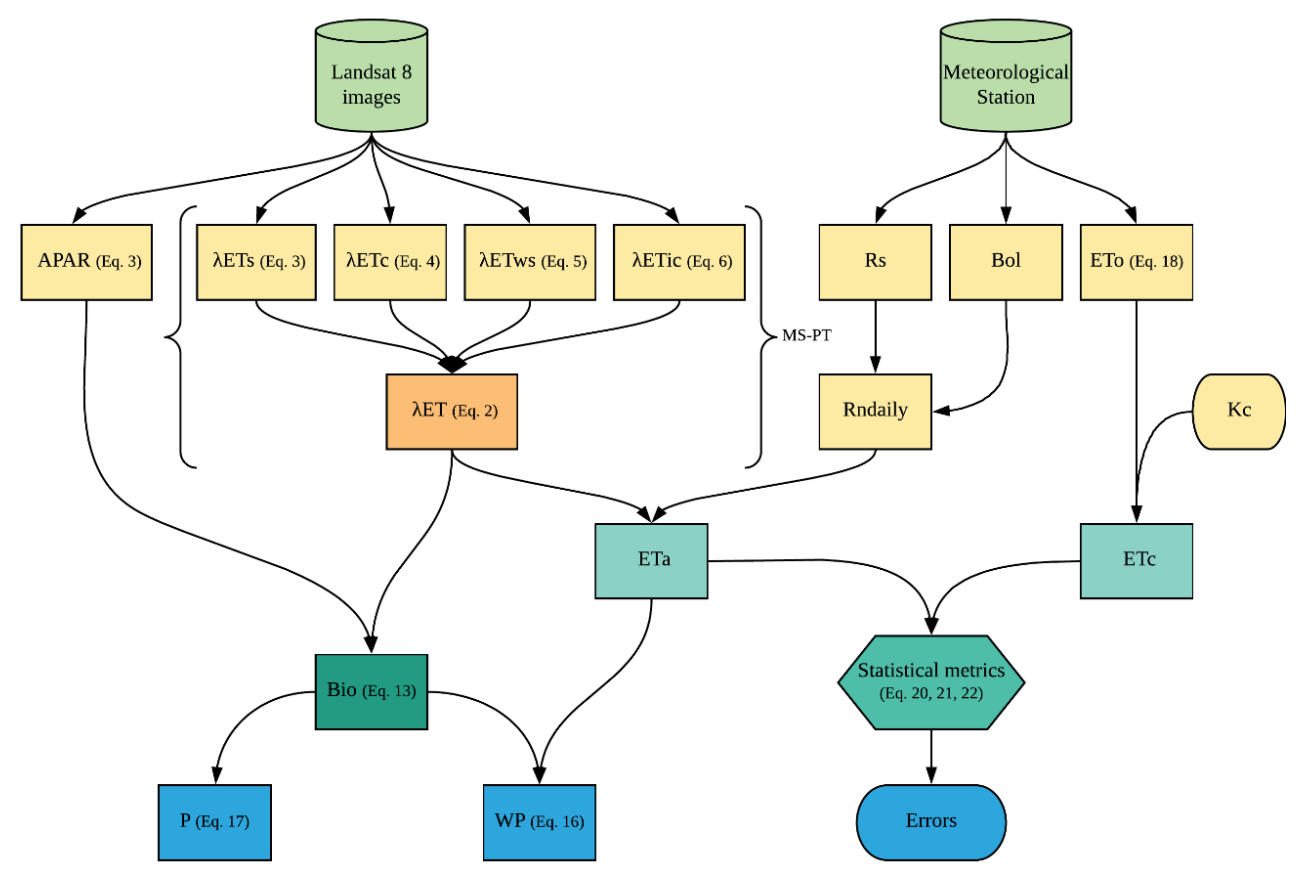


After the estimation of ETa, the daily biomass of the central pivots was calculated, using the model proposed by (MONTEITH, 1972). Water productivity was obtained by the ratio between these two variables (COAGUILA et al., 2017), and, finally, the daily biomass was integrated, finding total productivity throughout the crop cycle.

\section{Obtaining evapotranspiration - MS-PT}

To obtain the evapotranspiration, the algorithm based on the Priestley-Taylor equation was used, which is denominated MS-PT, according to the methodology presented in Yao et al. (2013) and Zhang et al. (2017b). The model is based on the experiences of the theoretical and practical combination proposed by (PRIESTLEY; TAYLOR, 1972) that gave rise to the following latent heat flux equation (Equation 1):

$$
\lambda \mathrm{ETa}=\alpha \frac{\Delta}{\Delta+\mathrm{Y}}\left(\mathrm{R}_{\mathrm{n}}-\mathrm{G}\right)
$$

(Equation 1)

where is the latent heat flux, $\mathrm{W} \mathrm{m}^{2} ; \alpha$ is the nondimensional empirical coefficient (1.26); $\Delta$ is the derivative of the water vapor saturation function; $\mathrm{Y}$ is the psychrometric constant; $\mathrm{Rn}$ is the balance of radiation; and $\mathrm{G}$ is the heat flux in the soil.

In order to minimize the need for the inclusion of meteorological parameters to obtain evapotranspiration, Yao et al. (2013) modified the original equation (Equation 1). The authors inserted variables of vegetation indices (VIs) and apparent thermal inertia (ATI), in addition to derived variables, thus elaborating the MS-PT algorithm, which is based on obtaining the actual latent heat flux $(\lambda \mathrm{ETa})$, according to Equation 2.

$$
\lambda \mathrm{ETa}^{2} \lambda \mathrm{ET}_{\mathrm{s}}+\lambda \mathrm{ET}_{\mathrm{c}}+\lambda \mathrm{ET}_{\mathrm{ws}}+\lambda \mathrm{ET}_{\mathrm{ic}} \quad(\text { Equation 2) }
$$

where $\lambda \mathrm{ET}_{\mathrm{s}}$ is the latent heat flux related to the evaporation of the unsaturated soil, in $\mathrm{W} \mathrm{m} \mathrm{m}^{-2}$ (Equation 3); $\lambda \mathrm{ET}_{\mathrm{c}}$ is the latent heat flux related to canopy transpiration, in $\mathrm{W} \mathrm{m}^{-2}$ (Equation 4$) ; \lambda \mathrm{ET}_{\mathrm{ws}}$ is the latent heat flux for saturated evaporation of the wet soil surface, in $\mathrm{W} \mathrm{m}^{-2}$ (Equation 5); and $\lambda \mathrm{ET}_{\text {ic }}$ is the latent heat flux related to the evaporation of water intercepted by the canopy, in $\mathrm{W} \mathrm{m}^{-2}$ (Equation 6). The $\lambda \mathrm{ET}_{\mathrm{s}}$ is computed as follows:

$$
\lambda \mathrm{ET}_{\mathrm{s}}=\left(1-\mathrm{f}_{\mathrm{wet}}\right) \mathrm{f}_{\mathrm{sm}} \alpha \frac{\Delta}{\Delta+\mathrm{Y}}\left(\mathrm{R}_{\mathrm{ns}}-\mathrm{G}\right) \quad(\text { Equation } 3)
$$

where is the fraction of the wet surface, which is calculated on the basis of the fourth power of the soil moisture restriction (, which, in turn, is calculated based on the apparent inertia of the temperature (ATI), which can be simplified as the inverse of the temperature range of the day (Equation 7); $\mathrm{R}_{\mathrm{ns}}$ is the soil radiation balance, calculated according to Equation 8; and $\mathrm{G}$ is the heat flux in the soil (Equation 9). The $\lambda \mathrm{ETc}$ is computed as follows:

$$
\left.\lambda \mathrm{ET}_{\mathrm{c}}=\left(1-\mathrm{f}_{\mathrm{wet}}\right) \mathrm{f}_{\mathrm{c}} \mathrm{f}_{\mathrm{T}} \alpha \frac{\Delta}{\Delta+\mathrm{Y}}\left(\mathrm{R}_{\mathrm{nv}}\right) \quad \text { (Equation } 4\right)
$$

where is the cover fraction, calculated according to Equation 10; is the plant temperature restriction, which is calculated according to Equation 11; and $R_{n v}$ is the radiation balance of the vegetation, calculated according to Equation 12. The $\mathrm{ET}_{\mathrm{ws}}$ and $\mathrm{ET}_{\text {ic }}$ are computed according to Equations 5 and 6 below:

$$
\begin{array}{ll}
\lambda \mathrm{ET}_{\mathrm{ws}}=\mathrm{f}_{\mathrm{wet}} \alpha \frac{\Delta}{\Delta+\mathrm{Y}}\left(\mathrm{R}_{\mathrm{ns}}-\mathrm{G}\right) & \text { (Equation 5) } \\
\lambda \mathrm{ET}_{\mathrm{ic}}=\mathrm{f}_{\mathrm{wet}} \alpha \frac{\Delta}{\Delta+\mathrm{Y}}\left(\mathrm{R}_{\mathrm{nv}}\right) & \text { (Equation 6) }
\end{array}
$$

The estimate of the moisture restriction $f_{s m}$ is necessary for the calculation of $f_{\text {wet }}$, which enters into the calculations of Equations 3, 4, 5 and 6. The $\mathrm{f}_{\mathrm{sm}}$ is computed according to the following equation:

$$
\mathrm{f}_{\mathrm{sm}}=\mathrm{ATI}^{\mathrm{k}}=\left(\frac{1}{\mathrm{DT}}\right)^{\frac{\mathrm{DT}}{\mathrm{DT}_{\max }}}
$$

(Equation 7)

where DT is the amplitude of the diurnal temperature relative to the day of the passage of the satellite and $\mathrm{DT}_{\max }$ the amplitude of the maximum diurnal temperature in the interval, which was considered constant in the equation, being assigned the value of $40{ }^{\circ} \mathrm{C}$ (YAO et al., 2013). 
The $\mathrm{R}_{\mathrm{ns}}$, in $\mathrm{W} \mathrm{m} \mathrm{m}^{-2}$, is used in the partitions referring to the latent heat fluxes of the soil $\left(\mathrm{ET}_{\mathrm{s}}\right.$ and $\left.\mathrm{ET}_{\mathrm{ws}}\right)$, this variable being estimated as follows:

$$
\mathrm{R}_{\mathrm{ns}}=\mathrm{R}_{\mathrm{n}}\left(1-\mathrm{f}_{\mathrm{c}}\right) \quad \text { (Equation 8) }
$$

where $\mathrm{R}_{\mathrm{n}}$ is the radiation balance, in $\mathrm{W} \mathrm{m} \mathrm{m}^{-2}$, which was calculated in this study according to (BASTIAANSSEN et al., 1998). For the calculation of $R_{n s}$, it is necessary to calculate $f_{c}$, which can be estimated by Equation 9 .

$$
\mathrm{f}_{\mathrm{c}}=\left(\frac{\mathrm{NDVI}-\mathrm{NDVI} \mathrm{I}_{\min }}{\mathrm{NDVI}_{\max }-\mathrm{NDVI}_{\min }}\right) \quad \text { (Equation 9) }
$$

As with the $R_{n s}$, the $G$, in $W m^{-2}$ is estimated for the latent heat flux partitioning relative to the ground, being calculated by Equation 10 .

$$
\mathrm{G}=0.18\left(1-\mathrm{f}_{\mathrm{c}}\right) \mathrm{R}_{\mathrm{n}}
$$

(Equation 10)

where NDVI is the Normalized Difference Vegetation Index (ROUSE JUNIOR et al., 1974), with maximum and minimum values being considered as 0.05 and 0.95 , respectively, for coverage fraction purposes (YAO et al., 2013).

For the estimation of $\mathrm{ET}_{\mathrm{c}}$, it is necessary to calculate $\mathrm{f}_{\mathrm{T}}$, which can be estimated according to Equation 11 below:

$$
\mathrm{f}_{\mathrm{T}}=\exp \left[-\left(\frac{\text { Tmax-Topt }}{\text { Topt }}\right)^{2}\right]
$$

(Equation 11)

with being the optimum temperature $\left(25^{\circ} \mathrm{C}\right)$.

In order to calculate the latent heat fluxes related to vegetation partitioning ( $\mathrm{ET}_{\mathrm{c}}$ and $)$, it is necessary to estimate the $\mathrm{R}_{\mathrm{nv}}$, which can be estimated according to the following equation:

$$
\mathrm{R}_{\mathrm{nv}}=\mathrm{R}_{\mathrm{n}} \mathrm{f}_{\mathrm{c}}
$$

(Equation 12)

\section{Obtaining the daily biomass}

After the calculation of, the daily biomass (Bio, $\left.\mathrm{kg} \mathrm{ha}^{-1} \mathrm{~d}^{-1}\right)$, that is, the production of dry matter per unit of area on the day of image acquisition (BASTIAANSSEN; ALI, 2003; COAGUILA et al., 2017), was estimated by Equation 13.

$$
\mathrm{BIO}=\varepsilon_{\max } \text { Ef APAR } 0.864
$$

(Equation 13)

where $\varepsilon_{\max }$ is the maximum efficiency in the use of radiation, in $\mathrm{MJ}^{-1}$, according to Bastiaanssen and Ali (2003); Ef corresponds to the evaporativedimensionless fraction (Equation 14); and APAR is called photosynthetically active absorbed radiation $\left(\mathrm{W} \mathrm{m}^{-2}\right.$ ) (Equation 15) (BASTIAANSSEN; ALI, 2003).

$$
\mathrm{Ef}=\frac{\lambda \mathrm{ETa}}{\mathrm{R}_{\mathrm{n}}-\mathrm{G}}
$$

(Equation 14)

$\mathrm{APAR}=(1.26 \mathrm{NDVI}-0.16)(0.48 \mathrm{Rg})($ Equation 15)

The determination of APAR was carried out from a fraction of photosynthetically active radiation (PAR), which takes into account the NDVI and Rg, global solar radiation, in $\mathrm{W} \mathrm{m}^{-2}$ (TEIXEIRA et al., 2015).

\section{Obtaining crop yield and water productivity}

The water productivity, in $\mathrm{kg} \mathrm{m}^{-3}$, was obtained by the ratio between the biomass (BIO) and the actual evapotranspiration (ETa) obtained by the MS-PT. ETa was obtained by converting the from $\mathrm{W} \mathrm{m}{ }^{-2}$ to $\mathrm{mm} \mathrm{d}^{-1}$.

$\mathrm{WP}=\frac{\mathrm{BIO}}{\mathrm{ETa}}$

(Equation 16)

The estimated values of daily biomass were integrated for the entire maize crop, resulting in total biomass per cycle $\left(\mathrm{BIO}_{\text {total }}\right), \mathrm{kg} \mathrm{ha}^{-1} \mathrm{cycle}^{-1}$. After obtaining these values, the crop yield ( $\mathrm{P}, \mathrm{kg}$ $\mathrm{ha}^{-1}$ ) was determined based on the methodology proposed by Bastiaanssen and Ali (2003), according to Equation 17.

$$
\mathrm{P}=\frac{\mathrm{BIO}_{\text {total }} \mathrm{IC}}{1-\mathrm{Us}}
$$

(Equation 17)

where IC is the harvest index, dimensionless; and 
Us is the moisture on the wet basis of the grain during harvest, decimal.

In the present study, the IC of 0.40 was considered for maize (BASTIAANSSEN; ALI, 2003). We considered the maize moisture content of 14\% during harvest (AHRENS et al., 1998) and a $10 \%$ loss due to the harvest operation.

\section{Validation}

The ETa and total productivity data calculated by MS-PT were validated with estimates of standard FAO-56 (ALLEN et al., 1998) evapotranspiration (ETc), and productivity attained in the field, respectively. To calculate the ETc, the sequence according to Equations 18 and 19 was used.

The meteorological station data were downloaded, and the ETo was calculated using the standard equation recommended by FAO-56 (ALLEN et al., 1998), which considers, as reference, a surface cultivated with grass with a $0.12 \mathrm{~m}$ height, aerodynamic resistance of $70 \mathrm{~s} \mathrm{~m}^{-1}$ and albedo of 0.23 (Equation 18).

$$
\mathrm{ET}_{o}=\frac{0,408 \Delta\left(\mathrm{R}_{\mathrm{n}}-\mathrm{G}\right)+\gamma \frac{900}{\mathrm{t}+273} \mathrm{u}_{2}\left(\mathrm{e}_{\mathrm{s}}-\mathrm{e}_{\mathrm{a}}\right)}{\Delta+\gamma\left(1+0,34 \mathrm{u}_{2}\right)}
$$

(Equation 18)

where $\mathrm{ET}_{\mathrm{o}}$ is the reference evapotranspiration, $\mathrm{mm}$ $\mathrm{d}^{-1} ; \mathrm{R}_{\mathrm{n}}$ is the surface radiation balance, $M J \mathrm{~m}^{-2} \mathrm{~d}^{-1}$; $\mathrm{G}$ is the heat flux in the soil, MJ m $\mathrm{m}^{-2} \mathrm{~d}^{-1}$ t is the mean air temperature, ${ }^{\circ} \mathrm{C} ; \mathrm{u}_{2}$ is the wind velocity at $2 \mathrm{~m}$ in height, $\mathrm{m} \mathrm{s}^{-1}$; $\mathrm{e}_{\mathrm{s}}$ is the vapor saturation pressure, $\mathrm{kPa} ; \mathrm{e}_{\mathrm{a}}$ is the current vapor pressure of the air, $\mathrm{kPa} ; \Delta$ is the slope of the saturation vapor pressure curve, $\mathrm{kPa}^{\circ} \mathrm{C}^{-1}$; and $\gamma$ is the psychometric coefficient, $\mathrm{kPa}{ }^{\circ} \mathrm{C}^{-1}$.

After the calculation of the ET, the Kc was taken into consideration, according to Equation 19 below:

$\mathrm{ETc}=\mathrm{ET}_{\mathrm{o}} \mathrm{K}_{\mathrm{c}}$

(Equation 19)

$\mathrm{Kc}$ is the cultivation coefficient according to FAO-56 for maize cultivation, along the different phenological stages (ALLEN et al., 1998).

To evaluate the performance of these methodologies, with respect to the estimates of ETa and $\mathrm{P}$, we used the following statistical metrics: root mean squared error (RMSE) and mean bias error (MBE), according to Equations 20 and 21.

$$
\begin{aligned}
& \mathrm{RMSE}=\sqrt{\frac{1}{\mathrm{n}} \sum_{\mathrm{i}=1}^{\mathrm{n}}(\mathrm{Oi}-\mathrm{Pi})} \\
& \mathrm{MBE}=\frac{1}{\mathrm{n}} \sum_{\mathrm{i}=1}^{\mathrm{n}}(\mathrm{Oi}-\mathrm{Pi})
\end{aligned}
$$

where $\mathrm{P}_{\mathrm{i}}$ is the values predicted by the models and $\mathrm{O}_{\mathrm{i}}$ are the observed values.

\section{Results and Discussion}

Figure 3 shows the spatial-temporal distribution and the descriptive statistics of the actual evapotranspiration in all the central pivots of the study area. It can observed that at the beginning of the maize growing season, 25/05/2015, the maize present in the five central pivots had a low evapotranspiration demand. The reference evapotranspiration estimated for this day was 3.6 $\mathrm{mm}$, while the mean ETa of the central pivots was $2.31 \mathrm{~mm}$. 
Figure 3. Actual evapotranspiration occurring in central pivots throughout the irrigated maize crop cycle.

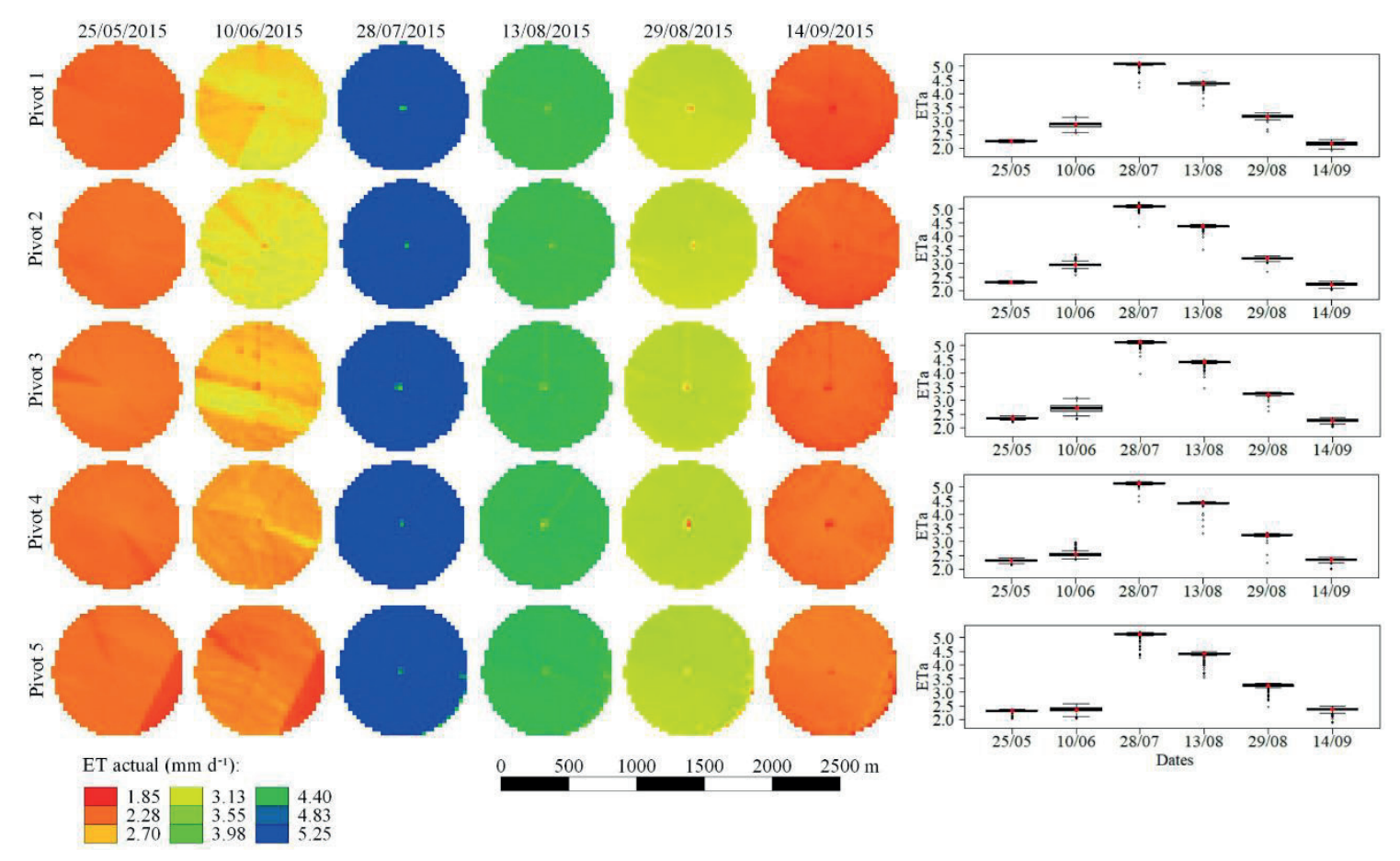

The peak of the evapotranspiration demand of maize grown in the central pivots occurred in the image of 28/07/2015, when the maize crop presented the highest stage of vegetative development, with 73, 70, 69, 67, 66 days after emergence (DAE) in pivots $1,2,3,4$ and 5 , respectively. Besides the crop being in full development stage, the meteorological variables resulted in a high reference evapotranspiration value, consequently resulting in high water requirement for the crop (ALLEN et al., 1998).

When analyzing Figure 3 on 10/06/2015, it is noted that there is, in all central pivots, a greater variability of ETa along the areas, which is perceived in the boxplot and qualitatively through the images. The cause of this heterogeneity may be related to several factors, such as crop development, soil variability, and water management, among others. However, the occurrence of heterogeneous values with a well-defined triangular geometric pattern may be related to the central pivot irrigation efficiency in the application of water in the crop.

The onset of a senescence period of the crop is evidenced by the abruptdrop in the evapotranspiration rate, notable on dates 29/08 and 14/09 (Figure 3), dates which the five center pivots already had 98 or more days after emergence (Table 1).

It is observed in Figure 4 that the daily biomass increase, as well as the evapotranspiration demand, had the highest peak in July 28, 2015, decreasing the increment after that date. 
Figure 4. Daily biomass production occurring in central pivots throughout the irrigated maize crop cycle.

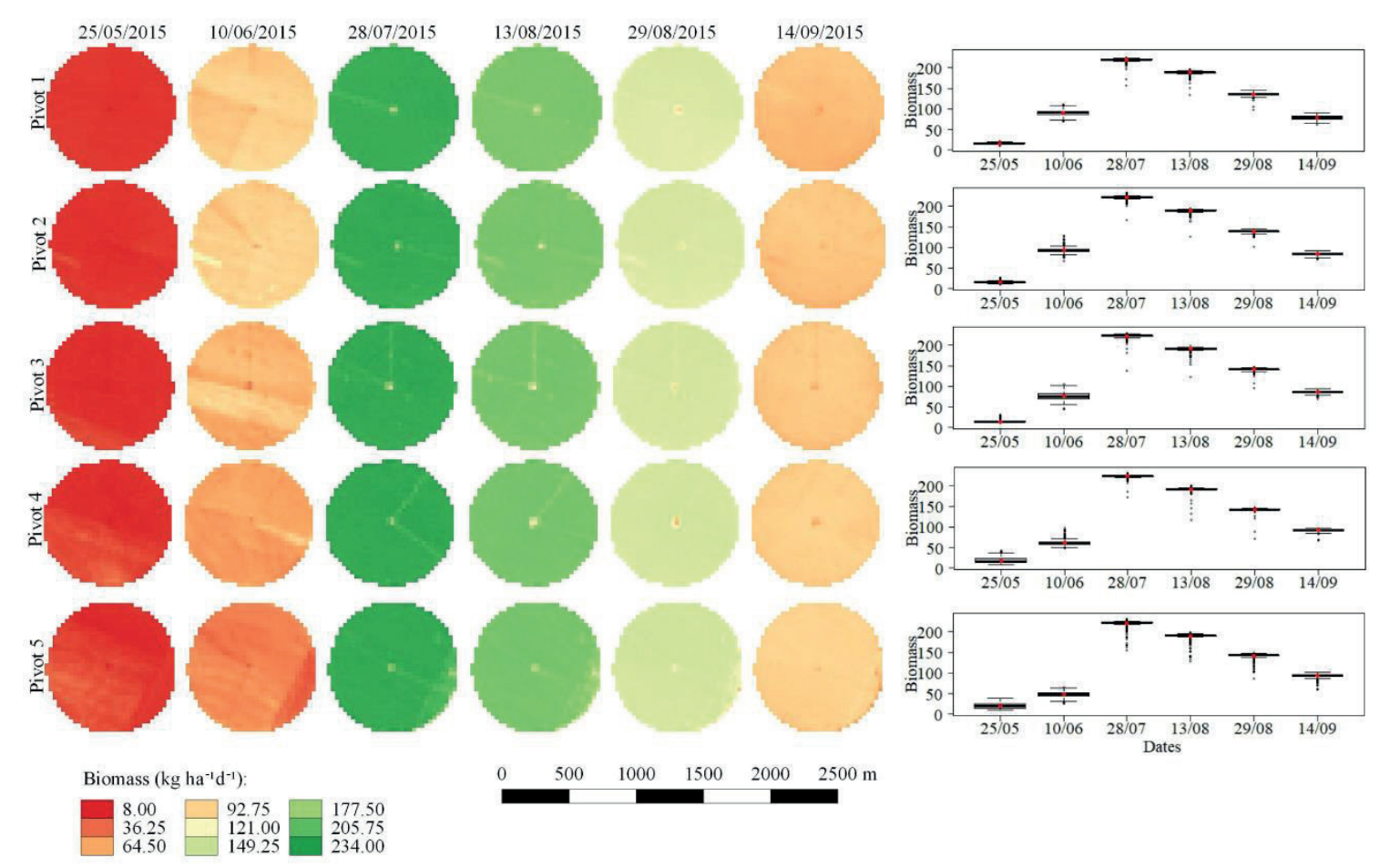

The daily biomass production showed a direct relationship to the evapotranspiration demand, that is, the higher the water demand of the crop, the higher the biomass production capacity. The analysis of the relationship between ETa and biomass allows us to verify that a crop that evapotranspirates in its full potential will express the productivity with greater relevance. Thus, the linear regression between ETa and the biomass for the dates of images is presented in Figure 5. This analysis shows a linear trend between these variables during the phenological crop cycle of the maize along the central pivots. No linear relationship between evapotranspiration demand and biomass production was found at the first date of the image acquisition $\left(\mathrm{r}^{2}=0.04\right)$ (Figure 5A). Until this date, the crop was still establishing itself in the areas, with 2 to 9 DAE, with predominance of soil exposed in the fields (Table 1). Thus, the evaporation component was the one that governed the evapotranspiration, not contributing to the entry of $\mathrm{CO}_{2}$ by the stomata of the plant and, consequently, not producing photoassimilates (ZHANG et al., 2017b). For the other dates, high determination coefficients $\left(\mathrm{r}^{2} \geq 0.89\right)$ between biomass and ETa data were found.

Campos et al. (2018) established a relationship of the coefficient of transpiration established by means of vegetation indices with the biomass production of maize and soybean, since there is a relationship between vegetation indices and crop production. These authors found coefficients of determination $\left(\mathrm{r}^{2}\right)$ of 0.94 to 0.96 for accumulated basal coefficient and biomass production. 
Figure 5. Relationship between ETa $\left(\mathrm{mm} \mathrm{d}^{-1}\right)$ and Bio $\left(\mathrm{kg} \mathrm{ha}^{-1} \mathrm{~d}^{-1}\right)$ along the dates of the images in the maize crop cycle: A) $25 / 05 / 2015$; B) 10/06/2015; C) 28/07/2015; D) 13/08/2015; E) 29/08/2015; F) 14/09/2015.
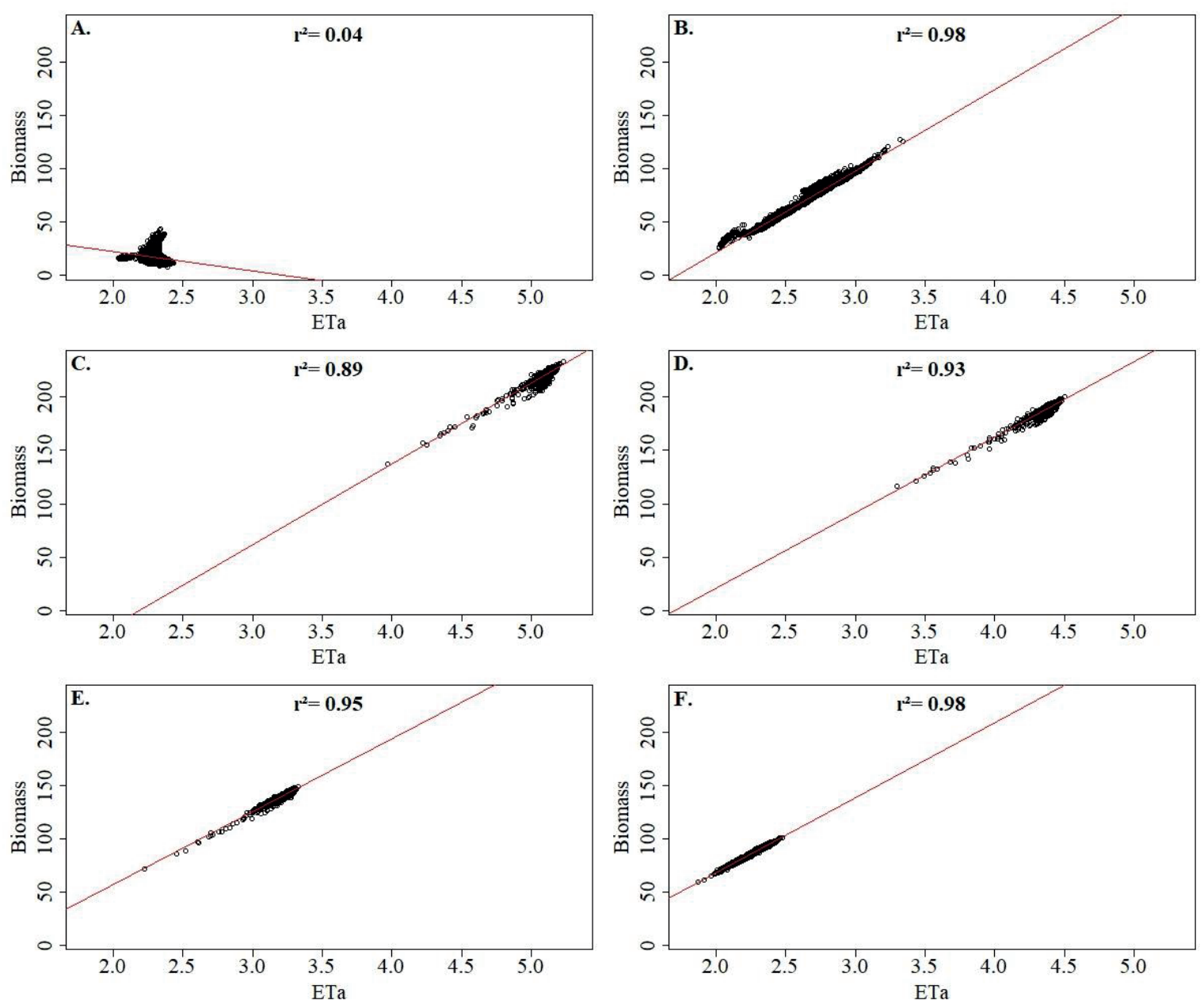

Figure 6 shows the results of the tests to evaluate the performance of the MS-PT algorithm on ETa estimation of the maize crop. It was observed that the largest discrepancies of the ETa, estimated by the algorithm MS-PT, occurred in the last two dates of the images used, that is, in the final portion of the irrigated maize crop cycle. This discrepancy cannot be accounted as an error as the standard FAO-56 estimate was used as the ground truth observation. It is known that innumerable other factors in the field, which are not perceptible in the standard method, can lead to a decrease in the evapotranspiration rate, this possibly being the fact that caused the fall of the ETa, and that was detected through the satellite images.

In addition, Westerhoff (2015) analyzed the errors caused by the estimation of FAO-56 standard reference evapotranspiration caused by the insertion of input data, since this is a methodology frequently used to validate the estimates made with remote sensing data. The analysis performed by this author found that the ETo values calculated by PenmanMonteith methods present uncertainties (10 to $40 \%$ ) that are more expressly caused by the errors in the measurement of air temperature data, followed by solar radiation.

Silva et al. (2018) estimated the evapotranspiration using the SEBAL Model for different land uses. These authors evaluated the estimation of evapotranspiration using the FAO- 
56 standard methodology and presented errors less than or equal to $1 \mathrm{~mm} \mathrm{~d}^{-1}$, validating the SEBAL methodology in obtaining ETc.
Minacapilli et al. (2016) estimated the ETa with precision, based on the triangle methodology and the Priestley-Taylor equation, a procedure referred to as the Time Domain Triangle Method (TDTM).

Figure 6. Validation of evapotranspiration data calculated by MS-PT with FAO-56 standard: A) RMSE - $\mathrm{mm} \mathrm{d}^{-1}$; B) MBE - $\mathrm{mm} \mathrm{d}^{-1}$.

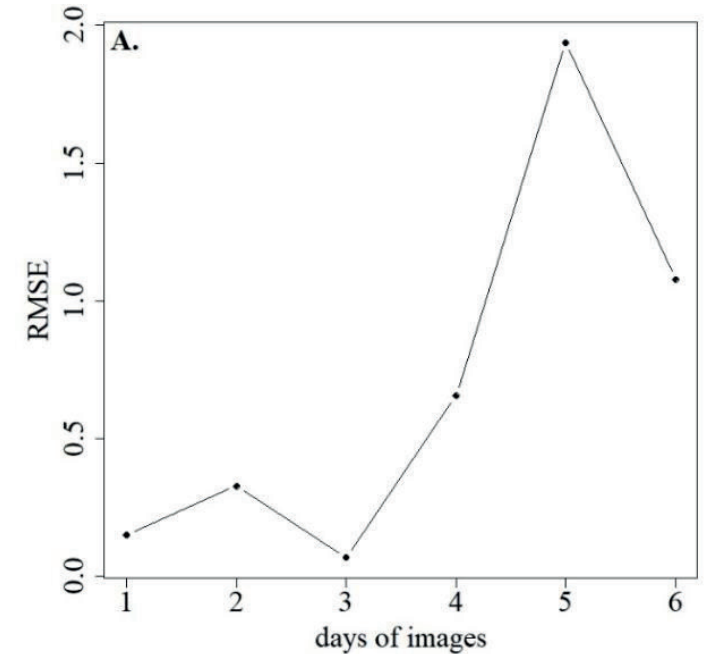

The WP obtained by the relationship between daily Bio and ETa is shown in Figure 7. This index is important for verifying the amount of water required to produce one kilogram of dry biomass above the ground of maize. It can be noticed that the behavior of water productivity had been similar to the already observed evapotranspiration and biomass behavior, but the high productivity of the water extends during the dates 28/07/2015, 13/08/2015 and 29/08/2015 (Figure 7). The decrease in the rate of ETa was accompanied by a reduction in the Bio increment of maize crops, a fact that caused water productivity to remain similar at these three dates. WP demonstrates how efficient the crop is in water use. The higher the productivity per cubic meter of water, the greater the efficiency of this crop. This parameter serves as an important indicator to verify which cultivar presents more efficient water use.

Coaguila et al. (2017) estimated the WP for annual crops in a region of the state of São Paulo,

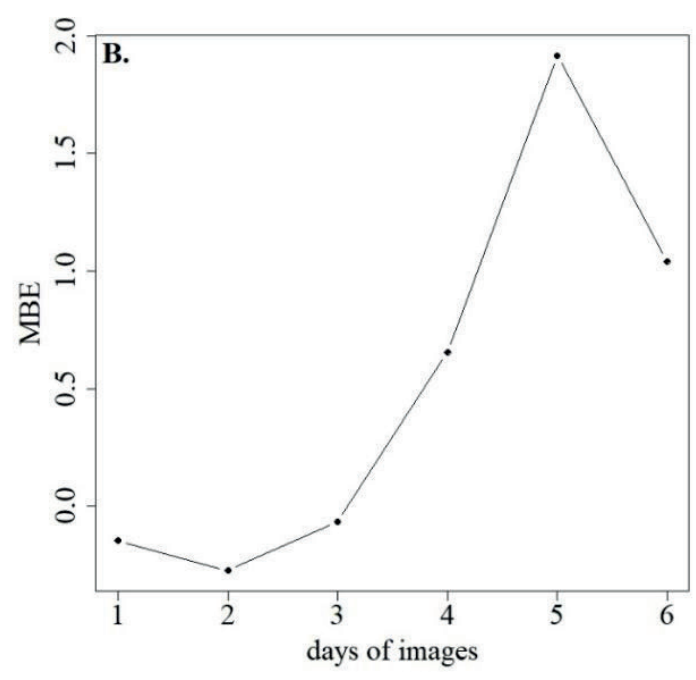

Brazil, and found an average value of $4.08 \mathrm{~kg} \mathrm{~m}^{-3}$ throughout the year 2015. In the present study, we found average values for the central pivots of $0.74,2.71,4.33,4.33,4.35$ and $3.82 \mathrm{~kg} \mathrm{~m}^{-3}$, on 25/05/2015, 10/06/2015, 28/07/2015, 13/08/2015, $29 / 08 / 2015$ and $14 / 09 / 2015$, respectively. In this way, it is possible to affirm that the phenological phases in which the crops showed to be more efficient in the use of water extended from 66 DAE (pivot 5) to $105 \mathrm{DAE}$ (pivot 1). At that time, the crop was between the tasseling phase (28/07/2015) and the phenological phase R4 (29/08/2015), characterized by pasty grains.

The total crop yield was derived from the daily biomass estimated for the days of the images. For this estimation, the following yields per hectare $\left(\mathrm{kg} \mathrm{ha}^{-1}\right)$ were obtained for the central pivots 1 to 5, respectively: 12,898.78; 12,492.09; 12,559.03; $12,509.55$ and $12,401.85$; where the values observed in the field were: $11,853.60 ; 13,023.60 ; 12,410.40$; 
$12,489.60 ; 12,234.00$. According to the results obtained and field yield observed, the following statistical metrics were: $532.20 \mathrm{~kg} \mathrm{ha}^{-1}$ (RMSE) and
$163.80 \mathrm{~kg} \mathrm{ha}^{-1}$ (MBE), presenting a relative error of $1.32 \%$, an estimate considered extremely accurate.

Figure 7. Water productivity of irrigated maize over the crop cycle in different central pivots.

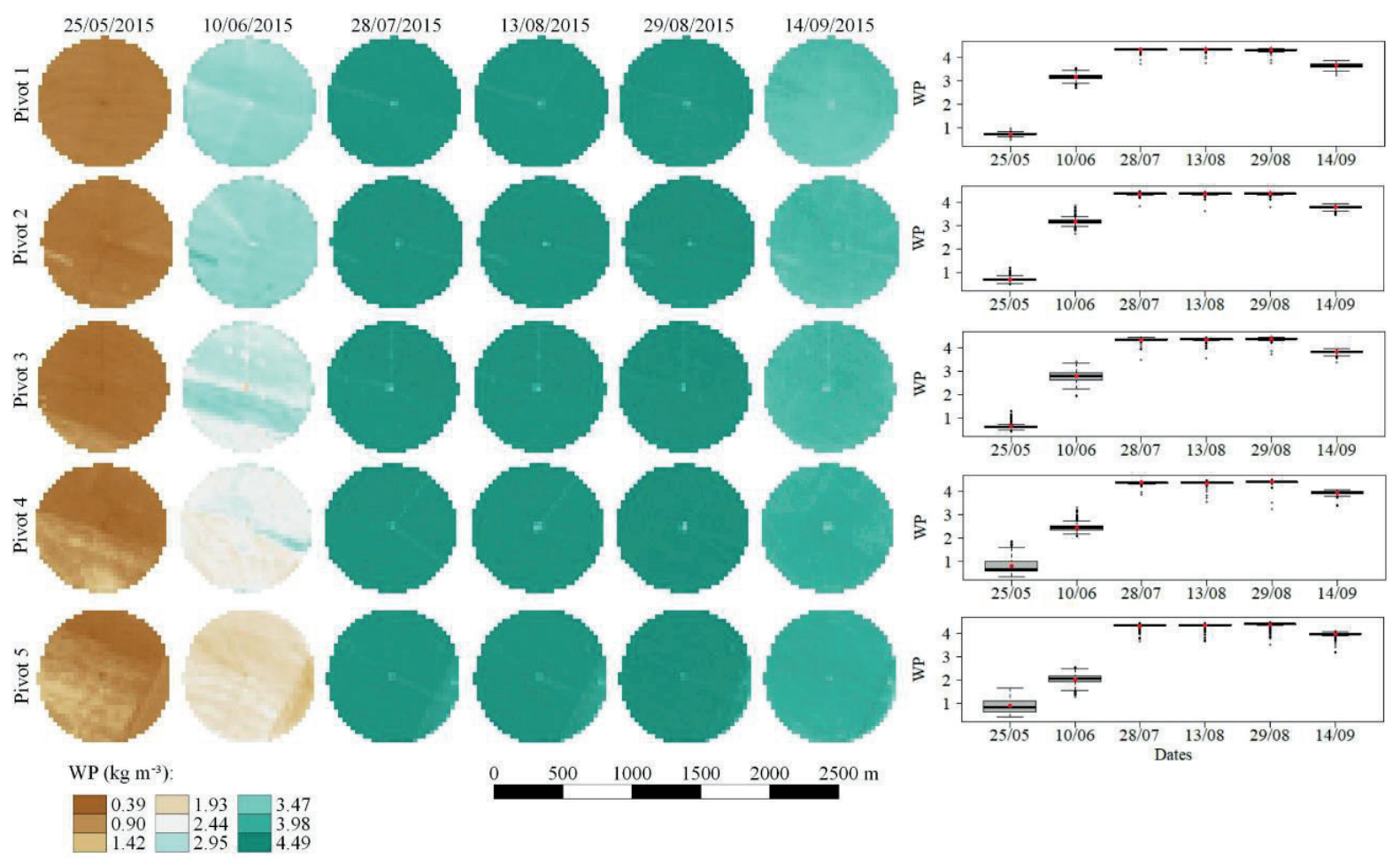

Bertolin et al. (2017) estimated the yield of irrigated maize for the same area of the present study and obtained a relative error of $-6.32 \%$ to the 2016 harvest. In the prediction, These authors used the relationship between NDVI (Normalized Difference Vegetation Index) and field productivity, requiring the occurrence of a historical database to model an equation.

The search for estimates of more accurate productivities through remote sensing is extremely important, since conventional estimation techniques are laborious and present errors that cannot be measured, such as situations involving interviews with farmers (MELO et al., 2008; RIZZI; RUDORF, 2007).

\section{Conclusion}

The MS-PT algorithm was extremely efficient from the initial phase (after emergence) to the beginning of the reproductive stage of the irrigated maize crop. After these phases, the assertiveness of the algorithm was lower when compared to the estimate of the standard FAO-56 ETc.

The evapotranspiration presented a direct relation with the biomass increment for the date 10/06 (18 days after the emergence), a fact that emphasizes the responsivity of the maize crop in relation to the water.

The water productivity remained constant during the maximum vegetative stage until reproductive phase R4 (pasty grain). 
The combination of algorithms used to predict the yield of irrigated maize presented high potential, given the accuracy reached in estimating productivity for irrigated maize crops.

\section{Acknowledgments}

We would like to thank the financial support (PhD scholarship) given by $\mathrm{CNPq}$ (Conselho Nacional de Desenvolvimento Científico e Tecnológico) and given by CAPES (Coordenação de Aperfeiçoamento de Pessoal de Nível Superior) to the first author. The authors also would like to thank the Triflora commercial farm and IRRIGER Irrigation management, for providing the field data.

\section{References}

ADNAN, M.; AHSAN, M.; REHMAN, A.; NAZIR, M. Estimating evapotranspiration using machine learning techniques. International Journal of Advanced Computer Science and Applications, Bradford, v. 8, n. 9, p. 108113, 2017. DOI: 10.14569/IJACSA.2017.080915

AHRENS, D. C.; BARROS, A. S. R.; VILLELA, F. A.; LIMA, D. Qualidade de sementes de milho (Zea mays L.) sob condições de secagem intermitente. Scientia Agricola, Curitiba, v. 55, n. 2, p. 320-341, 1998. DOI: 10.1590/S0103-90161998000200023

ALLEN, R. G.; PEREIRA, L. S.; RAES, D.; SMITH, M. Crop evapotranspiration: guidelines for computing crop water requirements. Rome: Food and Agriculture Organization of the United Nations, 1998. 300 p.

ALLEN, R. G.; TASUMI, M.; TREZZA, R. Satellitebased energy balance for mapping evapotranspiration with internalized calibration (METRIC) Model. Journal of Irrigation and Drainage Engineering, Washington, v. 133 , n. 4 , p. $380-394$, 2007. DOI: $10.1061 /(A S C E) 0733-$ 9437(2007)133:4(380)

ARAÚJO, A. L.; SILVA, M. T.; SILVA, B. B.; SANTOS, C. A. C.; AMORIM, M. R. B. Modelagem simplificada para estimativa do balanço de energia à superfície em escala regional (R-SSEB). Revista Brasileira de Meteorologia, São José dos Campos, v. 32, n. 3, p. 433446, 2017. DOI: $10.1590 / 0102-77863230010$

BASTIAANSSEN, W. G. M.; ALI, S. A new crop yield forecasting model based on satellite measurements applied across the Indus Basin, Pakistan. Agriculture, Ecosystems \& Environment, Amsterdam, v. 94, n. 3, p. 321-340, 2003. DOI: 10.1016/S0167-8809(02)00034-8

BASTIAANSSEN, W. G. M.; MENENTI, M.; FEDDES, R. A.; HOLTSLAG, A. A. M. A remote sensing surface energy balance algorithm for land (SEBAL). 1. Formulation. Journal of Hydrology, Amsterdam, v. $212-213$, p. $198-212$, 1998. DOI: $10.1016 /$ S00221694(98)00253-4

BERTOLIN, N. de O.; FILGUEIRAS, R.; VENANCIO, L. P.; MANTOVANI, E. C. Predição da produtividade de milho irrigado com auxílio de imagens de satélite. Revista Brasileira de Agricultura Irrigada, Fortaleza, v. 11, n. 4, p. 1627-1638, 2017. DOI: 10.7127/RBAI.V11N400567

CAMPOS, I.; NEALE, C. M. U.; ARKEBAUER, T. J.; SUYKER, A. E.; GONÇALVES, I. Z. Water productivity and crop yield: a simplified remote sensing driven operational approach. Agricultural and Forest Meteorology, Amsterdam, v. 249, p. 501-511, 2018. DOI: 10.1016/j.agrformet.2017.07.018

CARRILlO-ROJAS, G.; SILVA, B.; CÓRDOVA, M.; CÉLLERI, R.; BENDIX, J. Dynamic mapping of evapotranspiration using an energy balance-based model over an Andean páramo catchment of southern Ecuador. Remote Sensing, Basel, v. 8, n. 2, p. 160-184, 2016. DOI: $10.3390 / \mathrm{rs} 8020160$

CHAVEZ, P. S. An improved dark-object subtraction technique for atmospheric scattering correction of multispectral data. Remote Sensing of Environment, Amsterdam, v. 24, n. 3, p. 459-479, 1988. DOI: 10.1016/0034-4257(88)90019-3

COAGUILA, D. N.; HERNANDEZ, F. B. T.; TEIXEIRA, A. H. C.; FRANCO, R. A. M.; LEIVAS, J. F. Water productivity using SAFER Simple Algorithm for Evapotranspiration Retrieving in watershed. Revista Brasileira de Engenharia Agrícola e Ambiental, Campina Grande, v. 21, n. 8, p. 524-529, 2017. DOI: 10.1590/1807-1929/agriambi.v21n8p524-529

FENG, Y.; CUI, N.; GONG, D.; ZHANG, Q.; ZHAO, L. Modeling reference evapotranspiration using extreme learning machine and generalized regression neural network only with temperature data. Computers and Electronics in Agriculture, Amsterdam, v. 136, p. 71-78, 2017a. DOI: 10.1016/j.compag.2017.01.027

FENG, Y.; PENG, Y.; CUI, N.; GONG, D.; ZHANG, K. Evaluation of random forests and generalized regression neural networks for daily reference evapotranspiration modelling. Agricultural Water Management, Amsterdam, v. 193, p. 163-173, 2017b. DOI: 10.1016/j. agwat.2017.08.003 
KUSTAS, W. P.; HUMES, K. S.; NORMAN, J. M.; MORAN, M. S. Single and dual source modeling of surface energy fluxes with radiometric surface temperature. Journal of Applied Meteorology, Washington, v. 35, n. 1, p. 110-121, 1996. DOI: $10.1175 / 1520-0450(1996) 035<0110$ :SADSMO $>2.0$. $\mathrm{CO} ; 2$

LOBELL, D. B.; THAU, D.; SEIFERT, C.; ENGLE, E.; LITTLE, B. A scalable satellite-based crop yield mapper. Remote Sensing of Environment, Amsterdam, v. 164, p. 324-333, 2015. DOI: 10.1016/j.rse.2015.04.021

MELO, R. W.; FONTANA, D. C.; BERLATO, M. A.; DUCATI, J. R. An agrometeorological-spectral model to estimate soybean yield, applied to southern Brazil. International Journal of Remote Sensing, Oxfordshire, v. 29, n. 14, p. 4013-4028, 2008. DOI: 10.1080/01431160701881905

MINACAPILLI, M.; CONSOLI, S.; VANELLA, D.; CIRAOLO, G.; MOTISI, A. A time domain triangle method approach to estimate actual evapotranspiration: application in a Mediterranean region using MODIS and MSG-SEVIRI products. Remote Sensing of Environment, Amsterdam, v. 174, p. 10-23, 2016. DOI: 10.1016/j. rse.2015.12.018

MONTEITH, J. L. Solar radiation and productivity in tropical ecosystems. The Journal of Applied Ecology, Ann Arbor, v. 9, n. 3, p. 747-767, 1972. DOI: $10.2307 / 2401901$

MORILLO, J. G.; RODRÍGUEZ, D. J. A.; CAMACHO, E.; MONTESINOS, P. Linking water footprint accounting with irrigation management in high value crops. Journal of Cleaner Production, Amsterdam, v. 87, p. 594-602, 2015. DOI: $10.1016 /$ j.jclepro.2014.09.043

PONZONI, F.; SHIMABUKURO, Y.; KUPLICH, T. Sensoriamento remoto da vegetação. 2 . ed. atualizada e ampliada. São Paulo: Oficina de Textos, 2012. 160 p.

PRIESTLEY, C. H. B.; TAYLOR, R. J. On the assessment of surface heat flux and evaporation using large-scale parameters. Monthly Weather Review, Washington, v. 100, n. 2, p. 81-92, 1972. DOI: 10.1175/1520-0493(1972) $100<0081$ :OTAOSH $>2.3$. $\mathrm{CO} ; 2$

RIZZI, R.; RUDORF, B. F. T. Imagens do sensor MODIS associadas a um modelo agronômico para estimar a produtividade de soja. Pesquisa Agropecuária Brasileira, Brasília, v. 42, n. 1, p. 73-80, 2007. DOI: 10.1590/S0100204X2007000100010

ROUSE JUNIOR, J.; HAAS, R. H.; SCHELL, J. A.; DEERING, D. W. Monitoring vegetation systems in the Great Plains with ERTS. Washington: NASA, 1974. 309 p.

ROY, D. P.; WULDER, M. A.; LOVELAND, T. R. C. E. W.; ALLEN, R. G.; ANDERSON, M. C.; HELDER, D.; IRONS, J. R.; JOHNSON, D. M.; KENNEDY, R.; SCAMBOS, T. A.; SCHAAF, C. B.; SCHOTT, J. R.; SHENG, Y.; VERMOTE, E. F.; BELWARD, A. S.; BINDSCHADLER, R.; COHEN, W. B.; GAO, F.; HIPPLE, J. D.; HOSTERT, P.; HUNTINGTON, J.; JUSTICE, C. O.; KILIC, A.; KOVALSKYY, V.; LEE, Z. P.; LYMBURNER, L.; MASEK, J. G.; MCCORKEL, J.; SHUAI, Y.; TREZZA, R.; VOGELMANN, J.; WYNNE, R. H.; ZHU, Z. Landsat-8: science and product vision for terrestrial global change research. Remote Sensing of Environment, Amsterdam, v. 145, p. 154-172, 2014. DOI: 10.1016/j.rse.2014.02.001

SENAY, G. B.; FRIEDRICHS, M.; SINGH, R. K.; VELPURI, N. M. Evaluating Landsat 8 evapotranspiration for water use mapping in the Colorado River Basin. Remote Sensing of Environment, Amsterdam, v. 185, p. 171-185, 2016. DOI: 10.1016/j.rse.2015.12.043

SILVA, B. B.; MERCANTE, E.; BOAS, M. A. V.; WRUBLACK, S. C.; OLDONI, L. V. Satellite-based ET estimation using Landsat 8 images and SEBAL model. Revista Ciência Agronômica, Fortaleza, v. 49, n. 2, p. 221-227, 2018. DOI: 10.5935/1806-6690.20180025

SILVA, R. D.; SILVA, M. A. A.; CANTERI, M. G.; ROSISCA, J. R.; VIEIRA-JÚNIOR, N. A. Reference evapotranspiration for Londrina, Paraná, Brazil: performance of different estimation methods. Semina: Ciências Agrárias, Londrina, v. 38, n. 4, p. 2363-2374, 2017. DOI: $10.5433 / 1679-0359.2017 \mathrm{v} 38$ n4Supl1p2363

TEIXEIRA, A. H. C. Determining regional actual evapotranspiration of irrigated crops and natural vegetation in the São Francisco River Basin (Brazil) using remote sensing and Penman-Monteith Equation. Remote Sensing, Basel, v. 2, n. 5, p. 1287-1319, 2010. DOI: $10.3390 /$ rs 0251287

TEIXEIRA, A. H. C.; LEIVAS, J. F.; ANDRADE, R. G.; HERNANDEZ, F. B. T. Water productivity assessments with Landsat 8 images in the Nilo Coelho irrigation scheme. Irriga, Botucatu, v. 1, n. 2, p. 1-10, 2015. DOI:10.15809/irriga.2015v1n2p01

TOUREIRO, C.; SERRALHEIRO, R.; SHAHIDIAN, S.; SOUSA, A. Irrigation management with remote sensing: evaluating irrigation requirement for maize under Mediterranean climate condition. Agricultural Water Management, Amsterdam, v. 184, p. 211-220, 2017. DOI: $10.1016 /$ j.agwat.2016.02.010

WESTERHOFF, R. S. Using uncertainty of Penman and Penman-Monteith methods in combined satellite 
and ground-based evapotranspiration estimates. Remote Sensing of Environment, Amsterdam, v. 169, p. 102-112, 2015. DOI: 10.1016/j.rse.2015.07.021

YAO, Y.; LIANG, S.; CHENG, J.; LIU, S.; FISHER, J. B.; ZHANG, X.; JIA, K.; ZHAO, X.; QIN, Q.; ZHAO, B.; HAN, S.; ZHOU, G.; ZHOU, G.; LI, Y.; ZHAO, S. MODIS-driven estimation of terrestrial latent heat flux in China based on a modified Priestley-Taylor algorithm. Agricultural and Forest Meteorology, Amsterdam, v. 171-172, p. 187-202, 2013. DOI: 10.1016/j. agrformet.2012.11.016

ZHANG, K.; KIMBALL, J. S.; RUNNING, S. W. A review of remote sensing based actual evapotranspiration estimation: Areview of remote sensing evapotranspiration. Wiley Interdisciplinary Reviews: Water, New York, v. 3, n. 6 , p. $834-853$, 2016. DOI: $10.1002 /$ wat2.1168
ZHANG, L.; YAO, Y.; WANG, Z.; JIA, K.; ZHANG, X.; ZHANG, Y.; WANG, X.; XU, J.; CHEN, X. Satellitederived spatiotemporal variations in evapotranspiration over Northeast China during 1982-2010. Remote Sensing, Basel, v. 9, n. 11, p. 1140, 7 2017a. DOI: 10.3390/ rs9111140

ZHANG, Y.; CHIEW, F. H. S.; PEÑA-ARANCIBIA, J.; SUN, F.; LI, H.; LEUNING, R. Global variation of transpiration and soil evaporation and the role of their major climate drivers: global variation in evapotranspiration components. Journal of Geophysical Research: Atmospheres, New York, v. 122, n. 13, p. 6868-6881, 2017b. DOI: 10.1002/2017JD027025 
